\title{
ANALISIS PENGARUH FAKTOR INTERNAL DAN EKSTERNAL TERHADAP ROA PERBANKAN DI INDONESIA
}

\section{Meiky T. Taliwuna, David P. E. Saerang, Sri Murni}

Universitas Sam Ratulangi

\section{A R T I C L E I N F O}

Keywords: ROA, CAR, LFR, NPL, BITDRR, Inflation

Kata Kunci: $\quad$ ROA, CAR, LFR, NPL, BI7DRR, Inflasi.

Corresponding author:

Meiky T. Taliwuna

Meiky.taliwuna@banksulutgo.co.id
Abstract: Profitability analysis is the evaluation of a company's return on investment. ROA has become the key indicator of bank profitability and it measures the efficiency of banks' in utilizing it's resources for generating profit. The primary focus of this study is to examine the impacts of internal and external factors consist of Capital Adequacy Ratio (CAR), Loan to Funding Ratio (LFR), Non-Performing Loan (NPL), Bank Indonesia 7-Day (reverse) Repo Rate (BI7DRR) and Inflation Rate on Return on Asset (ROA) of banks in Indonesia. The empirical analysis is based on data of top 11 largest banks by total assets and consistenly listed on Indonesia Stock Exchange during 2016-2018. Multiple Linear Regression model were utilized in testing the 6 hypotheses. The findings of this study revealed that internal and external factors simultaneously have a statistically significant effect toward ROA of Bank in Indonesia. Furthermore, the result show that partially there is significant positive correlation impact on CAR toward ROA of Banks in Indonesia, as well as significant negative impact on NPL toward ROA. Meanwhile, there were no significant impact on LFR, BI7DRR, and Inflation Rate toward ROA.

Abstrak: Analisis profitabilitas adalah analisa tingkat pengembalian investasi perusahaan yang berfokus pada sumber daya perusahaan. ROA telah menjadi indikator utama yang digunakan perbankan untuk mengukur efisiensi pengelolaan sumber dana yang ada untuk menghasilkan laba. Tujuan penelitian ini dilakukan untuk menganalisis pengaruh faktor internal yang terdiri dari Capital Adequacy Ratio (CAR), Loan to Funding Ratio (LFR) dan NonPerforming Loan (NPL) serta faktor eksternal yaitu Bank Indonesia 7-Day (reverse) Repo Rate (BI7DRR) dan tingkat Inflasi terhadap profitabilitas perbankan di Indonesia yang diproksikan dengan Return On Asset (ROA) dilakukan dengan menganalisa laporan keuangan 11 perbankan dengan total aset terbesar di Indonesia yang secara konsisten terdaftar di Bursa Efek Indonesia tahun 2016-2018. Adapun metode statistik yang digunakan untuk menguji ke-6 model hipotesis yang telah ditentukan adalah metode regresi linear berganda dan regresi linear sederhana. Setelah diuji secara bersama-sama menunjukkan bahwa secara simultan faktor internal maupun eksternal berpengaruh signifikan terhadap profitabilitas perbankan di Indonesia periode 2016-2018. Hasil penelitian secara parsial menunjukkan bahwa CAR berpengaruh signifikan dan positif terhadap ROA perbankan serta NPL berpengaruh signifikan dan negatif terhadap ROA sedangkan LFR, BI7DRR, dan tingkat inflasi tidak berpengaruh signifikan terhadap naik turunnya ROA perbankan. 


\section{Latar Belakang Masalah}

\section{PENDAHULUAN}

Industri Perbankan Nasional merupakan industri yang memegang peranan penting dalam sistem keuangan di Indonesia, sehingga pertumbuhan ekonomi Indonesia sangat dipengaruhi oleh pengeloaan sistem perbankan yang kuat (Purwoko \& Sudiyatno, 2013). Menurut Bank Indonesia (2011) fungsi utama perbankan Indonesia adalah sebagai penghimpun dan penyalur dana masyarakat serta bertujuan untuk menunjang pelaksanaan pembangunan nasional dalam rangka meningkatkan pemerataan pembangunan dan hasil-hasilnya, pertumbuhan ekonomi dan stabilitas nasional, kearah peningkatan taraf hidup rakyat banyak.

Stabilitas sistem keuangan sampai dengan semester II 2018 tetap terjaga walaupun sempat mengalami tekanan akibat meningkatnya ketidakpastian ekonomi global. Kinerja sistem keuangan, baik dari sisi intermediasi, efisiensi, maupun ketahanan, terjaga dengan baik. Sejalan dengan pertumbuhan ekonomi domestik yang tetap kuat dan siklus keuangan di akhir semester I 2018 yang masih menunjukkan ruang untuk melakukan ekspansi, intermediasi yang dilakukan oleh sistem keuangan Indonesia mengalami peningkatan pertumbuhan (Bank Indonesia, 2019a). Secara umum stabilitas perekonomian tahun 2018 cukup terkendali dan berkontribusi pada pertumbuhan ekonomi sebesar 5,17\% lebih tinggi dibandingkan dengan tahun 2017 sebesar 5,07\% serta inflasi terkendali pada level rendah yakni 3,13\%, dan dalam kisaran sasaran 3,5 $1 \%$. Stabilitas sistem keuangan juga terjaga ditopang intermediasi perbankan yang naik, likuiditas yang tetap memadai, permodalan yang tinggi, dan risiko kredit yang terjaga. Dengan mempertimbangkan prospek perekonomian di tengah ketidakpastian global yang berisiko mengganggu ketahanan eksternal Indonesia, suku bunga kebijakan moneter Bank Indonesia 7-day (Reverse) Repo Rate (BI7DRR) dinaikkan hingga 175 bps untuk memperkuat daya tarik aset keuangan domestik dan menurunkan defisit transaksi berjalan. Bank Indonesia secara bertahap sejak Mei 2018 menaikkan BI7DRR hingga menjadi $6,00 \%$ pada 2018 . untuk mencapai sasaran inflasi sebesar $3,5 \pm 1 \%$ pada 2019 , serta $3,0 \pm 1 \%$ pada 2020 dan 2021. Di tahun 2018 Stabilitas sistem keuangan juga terkendali ditopang permodalan perbankan yang kuat dan likuiditas yang cukup. Rasio permodalan perbankan tetap tinggi dengan capital adequacy ratio (CAR) perbankan yang mencapai 22,9\% pada akhir 2018. Risiko kredit juga terkelola dengan baik yang tercermin dari rasio NPL yang tetap rendah yakni 2,4\% (gross) atau 1,0\% (nett) dan berada pada level sehat di bawah 5\% (Bank Indonesia, 2019b). Dilihat dari sisi likuiditas tetap terjaga seiring dengan dikeluarkannya peraturan terbaru mengenai giro wajib minimum bank umum dalam rupiah dan valuta asing dimana sebelumnya target LDR 78\% -100\% dan diubah lebih konservatif menjadi batas bawah Giro Wajib Minimum Loan to Funding Ratio 78\% dan batas atas 94\%. (Bank Indonesia, 2015).

Secara umum kondisi industri perbankan Indonesia berada pada situasi yang kondusif, namun pihak perbankan diharapkan terus menerapkan prinsip kehati-hatian karena secara nasional lembaga keuangan tetap harus mengantisipasi kemungkinan gejolak lanjutan krisis keuangan global (Sudiyatno \& Suroso, 2010) dan mendorong pihak-pihak yang terlibat di dalamnya untuk melakukan penilaian atas kesehatan bank. Tingkat kesehatan bank dapat dinilai berdasarkan tingkat profitabilitas bank yang merupakan tolok ukur kinerja perbankan (Dewi, Herawati, \& Sulindawati, 2015). Profitabilitas merupakan kemampuan bank untuk menghasilkan laba secara efektif dan efisien (Hendrayanti \& Muharam, 2013) sehingga penelitian tentang faktor-faktor penentu profitabilitas perbankan sangat penting terhadap pertumbuhan dan stabilitas ekonomi keseluruhan. (Abate \& Mesfin, 2019). Begitu banyak peneliti yang melakukan penelitian profitabilitas dengan perspektif yang berbeda serta variabel yang berbeda-beda. Tingkat profitabilitas perbankan dapat mempengaruhi stabilitas keuangan suatu Negara.

Terdapat empat ukuran profitabilitas yang ditentukan oleh Bank Indonesia yaitu ROA, ROE, NIM, dan BOPO. Para akademisi merekomendasikan ROA sebagai rasio utama untuk menilai profitabilitas perbankan (Abate \& Mesfin, 2019). Menurut Purwoko dan Sudiyatno (2013), faktor internal merupakan faktor yang secara spesifik mempengaruhi kinerja bank dan dapat dikendalikan oleh pihak manajemen. 
Faktor eksternal merupakan faktor yang tidak dipengaruhi oleh kebijakan dan keputusan manajemen. ROA digunakan sebagai indikator utama dalam penelitian ini karena ROA merupakan ukuran profitabilitas yang mengukur efisiensi perbankan dalam memanfaatkan sumber daya untuk menghasilkan laba.

Gambaran perkembangan rasio keuangan dari sebelas besar bank yang memiliki jumlah aset terbesar di Indonesia selama tahun 2016 - 2018 adalah sebagai berikut:

Tabel 1.1 Rata-rata kinerja keuangan 11 Besar Perbankan periode tahun 2016 - 2018

\begin{tabular}{crrr}
\hline Rasio (\%) & $\mathbf{2 0 1 6}$ & $\mathbf{2 0 1 7}$ & $\mathbf{2 0 1 8}$ \\
\hline ROA & 1,65 & 2,29 & 2,43 \\
CAR & 19,62 & 20,08 & 20,32 \\
LFR & 89,32 & 90,26 & 94,10 \\
NPL & 3,37 & 2,78 & 2,60 \\
\hline
\end{tabular}

Sumber: Data diolah dari Laporan Keuangan Perbankan tahun 2016 - 2018

Tabel 1.1 Rata-rata kinerja keuangan 11 Besar Perbankan periode tahun 2016 - 2018 menunjukkan bahwa seiring dengan keadaan perekonomian pada tahun penelitian 2016 - 2018 yang menunjukkan tren positif kinerja kuangan perbankan juga turut mengalami fluktuasi terlihat dari perolehan laba yang tercermin pada Return On Asset (ROA) perbankan yang terus mengalami perbaikan positif mengindikasikan kondisi efektivitas pengelolaan aset perbankan sesuai dengan kondisi perekonomian Indonesia yang terus mengalami pemulihan ditengah krisis global serta didukung oleh ekspansi kegiatan intermediasi yang diikuti dengan perbaikan kualitas kredit. Kemampuan modal Bank yang diproksikan dengan Capital Adequacy Ratio (CAR) dari Bank-bank dengan jumlah aset terbesar di Indonesia terlihat terus mengalami peningkatan mengindikasikan penguatan struktur permodalan yang terus di pertahankan. Pertumbuhan modal perbankan terutama bersumber dari kenaikan proftabilitas bank, disamping adanya tambahan modal yang bersumber dari right issue, modal pinjaman, dan dana setoran modal (Bank Indonesia, 2019).

Sisi likuiditas menunjukkan bahwa posisi Loan to Funding Ratio (LFR) ditahun 2018 melampaui batas maksimal yang ditetapkan oleh regulator berdasarkan Peraturan Bank Indonesia Nomor: 17/11/PBI/2015 dengan batas bawah LFR 78\% dan batas atas 94\% apabila memenuhi syarat-syarat yang tertuang dalam PBI tersebut hal ini dapat menyebabkan perbankan dapat dikenakan disinsentif karena peningkatan kredit tidak seiring dengan kenaikan proporsi dana pihak ketiga sehingga LFR terus mengalami peningkatan dalam tiga tahun periode penelitian membuat pihak perbankan harus lebih berhati-hati dalam melakukan ekspansi kredit, sementara dilihat dari sisi risiko kredit akibat gagal bayar yang berdampak pada kerugian Bank yang diukur dengan rasio Non-Performing Loan (NPL) terus mengalami perbaikan seiring dengan stabilitas perekonomian yang terus mengalami pemulihan serta adanya upaya mitigasi risiko kredit yang berkesinambungan dengan standar pemberian kredit yang prudent serta mengutamakan kredit yang berkualitas.

Berbicara mengenai kinerja perbankan dan perekonomian Nasional tidak hanya dipengaruhi oleh faktor internal perbankan saja namun dipengaruhi oleh faktor eksternal seperti suku bunga Bank Indonesia (BI Rate) yang kemudian kebijakan tersebut diubah menjadi BI-7 Day (Reverse) Repo Rate pada tanggal 19 agustus 2016 inflasi dan faktor makroekonomi lainnya.

Adapun kinerja faktor eksternal selama periode 2016 - 2018 di Indonesia adalah sebagai berikut:

Tabel 1.2. Perkembangan rata-rata BI-7Day (Reverse) Repo Rate dan Inflasi tahun 2016-2018

\begin{tabular}{lccc}
\hline Indikator & $\mathbf{2 0 1 6}$ & $\mathbf{2 0 1 7}$ & $\mathbf{2 0 1 8}$ \\
\hline $\boldsymbol{B I 7 D R R}$ & 6,00 & 4,56 & 5,08 \\
Inflasi & 3,00 & 3,60 & 3,10 \\
\hline
\end{tabular}

Sumber data: Bank Indonesia dan Badan Pusat Statistik tahun 2016-2018. 
Dilihat dari faktor makroekonomi pada Tabel 1.2 diatas menunjukkan bahwa rata-rata suku bunga Bank Indonesia (BI7DRR) berfluktuasi seiring dengan kondisi perekonomian Indonesia pada tahun penelitian serta sejalan dengan upaya Pemerintah untuk menjaga perekonomian domestik dan mempertahankan daya tarik aset keuangan guna memperkuat stabilitas eksternal ekonomi Indonesia. Dilihat dari sisi Inflasi selama periode penelitian laju inflasi terus terjaga satu sisi dipengaruhi faktor siklikal dari global dan domestik. Dari global, inflasi yang rendah dipengaruhi oleh harga pangan global yang menurun, yang kemudian berpengaruh positif pada tetap terkendalinya harga pangan domestik. Permintaan yang terkendali juga mempengaruhi tekanan inflasi yang terus menurun. (Bank Indonesia, 2019). Kedepan prospek Inflasi akan tetap terkendali akan ditopang oleh inflasi inti yang terjaga seiring tekanan dari sisi permintaan yang dapat direspons oleh sisi produksi secara memadai, ekspektasi inflasi yang terjangkar, dan nilai tukar rupiah yang terkendali. (Bank Indonesia, 2019)

Penelitian mengenai faktor-faktor yang mempengaruhi profitabilitas perbankan terus dilakukan, namun mendapatkan hasil yang beragam Seperti penelitian yang dilakukan oleh Sukarno dan Syaichu (2006) yang menggunakan variabel CAR, LDR, NPL, debt to equity ratio (DER), dan biaya operasional terhadap pendapatan operasional (BOPO) hasil penelitian menyatakan bahwa variabel CAR dan NPL berpengaruh secara positif terhadap ROA, sedangkan variabel BOPO berpengaruh secara negatif terhadap ROA dan untuk variabel NPL dan DER tidak berpengaruh signifikan terhadap ROA perbankan di Indonesia tahun 2000 -2004. Adapula penelitian yang dilakukan oleh Dwijayanthy dan Naomi (2009) yang mengukur profitabilitas perbankan dari faktor eksternal yaitu Inflasi, BI rate dan nilai tukar rupiah terhadap profitabilitas bank tahun 2003-2007 dimana hasil penelitian menunjukkan bahwa inflasi dan nilai tukar berpengaruh secara negatif dan signifikan sedangkan BI Rate tidak berpengaruh signifikan.

Penelitian yang berbeda juga dilakukan oleh Hendrayanti \& Muharam (2013) yang melakukan penelitian dengan mempertimbangkan pengaruh faktor internal yang mencakup equity to total asset ratio (EAR), BOPO, loan to asset ratio (LAR), dan volatilitas ROA serta faktor eksternal yang mencakup ukuran perusahaan (Firm Size), pertumbuhan ekonomi dan inflasi terhadap profitabilitas perbankan yang diproksikan dengan ROA hasil penelitian menunjukkan bahwa EAR dan Firm Size berpengaruh secara positif terhadap ROA, sedangkan BOPO dan LDR berpengaruh negatif terhadap ROA serta variabel pertumbuhan dan ekonomi tidak berpengaruh signifikan terhadap ROA.

Keragaman hasil penelitian diatas dapat dipengaruhi oleh perbedaan indikator, perbedaan objek dan negara penelitian, perbedaan perekonomian serta perbedaan tahun-tahun penelitian mendorong penelitian ini dilakukan. ROA digunakan sebagai indikator profitabilitas dengan asumsi ROA mencerminkan kinerja perbankan dari efisiensi pengelolaan aktiva yang dimiliki dalam menghasilkan laba dengan mempertimbangkan pengaruh faktor internal dengan mempertimbangkan risiko kecukupan modal, likuiditas dan risiko kredit sehingga variabel yang digunakan mencakup CAR, LDR serta NPL dan pengaruh makroekonomi atau faktor ekstenal yang terdiri dari BI-7 Day (Reverse) Repo Rate, dan inflasi.

Penelitian ini menggunakan data 11 besar perbankan Nasional yang memiliki jumlah aset terbesar di Indonesia pada tahun 2016-2018 dan berdasarkan data statisik perbankan jumlah asetnya telah mewakili mencapai Rp. 5.576.69 Triliun Rupiah yang telah mewakili 69.11\% dari total aset perbankan di Indonesia periode desember 2018 yang mencapai 8.068.34 Triliun Rupiah (Otoritas Jasa Keuangan, 2018a) dan memegang peranan penting terhadap peta perbankan di Indonesia dan berlomba-lomba dalam meningkatkan kinerja. Tahun 2016 - 2018 digunakan sebagai tahun penelitian dengan asumsi pada tiga tahun ini merupakan tahun yang penuh tantangan bagi perekonomian Indonesia setelah melewati krisis ekonomi global serta adanya perubahan variabel pengukuran kinerja keuangan perusahaan oleh regulator yaitu LDR menjadi LFR berdasarkan PBI nomor 17/11/PBI/2015 dan diberlakukannya BI-7 Day (Reverse) Repo Rate menggantikan BI-Rate sejak 19 Agustus 2019. Hasil penelitian ini diharapkan dapat memberikan gambaran bagaimana ketahanan dan strategi perbankan dalam menghadapi kondisi perekonomian yang berbeda dalam mengoptimalkan kinerja yang tercemin dalam ROA. 
Berdasarkan empirical gap yang menguraikan mengenai ketidakseimbangan ekonomi yang mempengaruhi stabilitas sistem keuangan dimana faktor-faktor yang mempengaruhi dapat bersumber dari pengaruh internal perbankan maupun dari faktor ekstenal yang disebut dengan faktor makroekonomi serta adanya perbedaan hasil-hasil penelitian terdahulu, maka penelitian ini dilakukan untuk menjawab beberapa perumusan masalah sebagai berikut:

1. Apakah CAR, LFR, NPL, BI-7DRR dan Inflasi secara simultan berpengaruh signifikan terhadap ROA

2. Apakah CAR secara parsial berpengaruh signifikan terhadap ROA?

3. Apakah LFR secara parsial berpengaruh signifikan terhadap ROA?

4. Apakah NPL secara parsial berpengaruh signifikan terhadap ROA?

5. Apakah BI-7DRR secara parsial berpengaruh signifikan terhadap ROA?

6. Apakah Inflasi secara parsial berpengaruh signifikan terhadap ROA?

\section{TINJAUAN PUSTAKA}

\section{Landasan Teori}

Bank

Sektor perbankan memegang peranan penting dalam menunjang pembangunan ekonomi dengan memobilisasi dana masyarakat dan kemudian disalurkan kembali dalam bentuk kredit. (Rawlin et al, 2014). Dengan demikian, pelaku ekonomi yang membutuhkan dana untuk menunjang kegiatannya dapat terpenuhi sehingga roda perekonomian dapat bergerak (Dewi et al, 2015). Menurut Bank Indonesia (2011) Perbankan adalah segala sesuatu yang berkaitan dengan bank, mencakup kelembagaan, kegiatan usaha, serta cara dan proses dalam melaksanakan kegiatan usahanya.

Return onf Asset (ROA)

Analisis profitabilitas adalah analisa tingkat pengembalian investasi perusahaan yang berfokus pada sumber daya perusahaan dan tingkat perolehan laba termasuk identifikasi dan pengukuran dampak dari pemanfaatan berbagai sarana yang dapat menghasilkan laba. Analisis profitabilitas juga berfokus pada alasan perubahan profitabilitas dan cara mempertahankan pendapatan. (Subramanyam \& Wild (2019), Tulung \& Ramdhani (2018)).

Pembahasan Sumbramanyam \& Wild (2019) profitabilitas lebih di fokuskan kepada return on invested capital (ROIC) dengan pengukuran yang lebih diarahkan kepada return on net operating asset (RNOA) dan return on common equity (ROCE) yang mengindikasikan bahwa pengukuran profitabilitas berbeda karena berbedanya perspektif.

Pembagian aktivitas operasi lebih cenderung berfokus kepada usaha manufakturing dimana aktivitas operasi merupakan merupakan aktivitas inti dari perusahaan.

ROA merupakan komponen dari tingkat investasi perusahaan. Perhitungan ROA untuk industri secara keseluruhan adalah:

$$
\mathrm{ROA}=\frac{\text { Net Income }+ \text { Interest Expense } \mathrm{x}(1-\text { Tax Rate })}{\text { Average total assets }}
$$

Dilihat dari sudut pandang usaha perbankan, ROA merupakan rasio yang digunakan untuk mengukur kemampuan bank dalam mengelola aktiva untuk menghasilkan laba. ROA mengindikasikan kemampuan bank menghasilkann laba dengan menggunakan asetnya, semakin besar rasio ini mengindikasikan semakin baik kinerja bank. (Purwoko \& Sudiyatno, 2013). Senada dengan itu, Abdullah, Parvez, dan Ayreen (2014) menjelaskan bahwa ROA digunakan untuk mengevaluasi kompetensi dan kinerja operasional dalam menghasilkan laba dari aset yang dimiliki bank dengan kata lain ROA digunakan 
untuk mengukur efektifitas perusahaan dalam menghasilkan keuntungan dengan memanfaatkan aktiva yang dimilikinya.

ROA industri perbankan dirumuskan sebagai berikut:

$$
\mathrm{ROA}=\frac{\text { Laba sebelum pajak }}{\text { Rata }- \text { rata total aset }} \times 100 \%
$$

Berdasarkan Peraturan Bank Indonesia Nomor: 13/1/PBI/2011 tentang "penilaian tingkat kesehatan bank umum." ROA merupakan komponen rentabilitas (earnings) dan menjadi salah satu faktor yang digunakan untuk menilai tingkat kesehatan Bank. Menurut Flamini, McDonald, Sumacher (2009) penggunaan ROA dalam analisa profitabilitas bisa menjadi bias ketika digunakan untuk analisa aktivitas diluar neraca (off-balance sheet), namun dalam penelitian ini tetap digunakan ROA karena kesulurahan data yang digunakan dalam analisa adalah data yang telah dipublikasi dan dinyatakan dalam laporan keuangan. ROA bermanfaat bagi manajemen perusahaan dalam menentukan arah kebijakan dan strategi perusahaan dan bagi para pemegang saham pemodal ROA bermanfaat menentukan besarnya prospek investasi suatu perusahaan kedepan.

\section{Capital Adequacy Ratio (CAR)}

CAR adalah suatu rasio yang menunjukkan sampai sejauh mana kemampuan permodalan suatu bank untuk mampu menyerap risiko kegagalan kredit yang mungkin terjadi (Purwoko \& Sudiyatno, 2013). CAR diperlukan untuk menciptakan sistem perbankan yang sehat dan mampu berkembang serta bersaing yang mampu menyerap risiko yang disebabkan oleh kondisi krisis dan atau pertumbuhan kredit perbankan yang berlebihan.

CAR yang dalam terminologi Bank Indonesia dikenal sebagai Rasio Kewajiban Penyediaan Modal Minimum yang selanjutnya disingkat KPMM adalah rasio antara modal terhadap aset tertimbang menurut risiko sebagaimana dimaksud dalam ketentuan mengenai kewajiban penyediaan modal minimum bank umum. (Bank Indonesia, 2015).

Menurut Otoritas Jasa Keuangan (2018) "Permodalan merupakan salah satu fokus utama otoritas pengawas bank dalam menerapkan prinsip kehati-hatian. Basel Committee on Banking Supervision (BCBS) telah menetapkan kerangkan permodalan untuk menjadi standar internasional sejak tahun 1988 menetapkan Aktiva Tertimbang Menurut Risiko (ATMR) khusus untuk risiko kredit, tahun 1996 menyempurnakan komponen modal dengan menambahkan Tier 3 serta perhitungan ATMR Risiko Pasar, tahun 2006 mengeluarkan Basel II, tahun 2009 mengeluarkan rekomendasi Basel 2,5 yang mencakup kerangka perhitungan ATMR Risiko Pasar denan menggunakan internal model, pengenaan beban modal untuk transaksi sekuritisasi, aspek Manajemen risiko untuk kompensasi, risiko konsentrasi, risiko reputasi, dan stress testing, valuasi atas seluruh eksposur yang dicatat berdasarkan fair value, dan pengungkapan sekuritisasi serta tahun 2010 mengeluarkan rekomendasi peningkatan ketahanan bank baik di level mikro maupun makro yang dikenal dengan kerangka basel III.

Kerangka Basel II (Pilar 1,2 dan 3) di Indonesia telah diimplementasi secara penuh sejak Desember 2012 melalui peraturan mengenai kewajiban penyediaan modal minimum di Indonesia tertuang dalam PBI No. 15/12/PBI/2013 yang menyatakan bahwa bank dalam rangka menciptakan perbankan yang sehat dan mampu berkembang, meningkatkan kemampuan bank untuk menyerap risiko dan dalam rangka meningkatkan kualitas modal, bank perlu membentuk tambahan modal di atas persyaratan penyediaan modal minimum sesuai dengan profil risiko yang berfungsi sebagai penyangga (buffer) apabila terjadi krisis keuangan dan ekonomi yang dapat mengganggu stabilitas keuangan. Sehingga ditetapkan paling rendah sebagai berikut: $8 \%$ dari aset tertimbang menurut risiko (ATMR) untuk bank dengan profil risiko peringkat satu, $9 \%-<10 \%$ dari ATMR untuk bank dengan profil risiko peringkat dua, $10 \%-<11 \%$ dari ATMR 
untuk bank dengan profil risiko peringkat tiga dan 11\% - 14\% dari ATMR untuk bank dengan profil risiko peringkat 4 atau peringkat 5 dengan perhitungan sebagai berikut:

Rumus perhitungan CAR adalah sebagai berikut:

$$
\mathrm{CAR}=\frac{\text { Modal bank }}{\text { Aktiva tertimbang menurut resiko }} \times 100
$$

Loan to Deposit Ratio (LDR) yang kemudian diubah menjadi Loan to Funding Ratio sesuai dengan PBI Nomor 17/11/PBI/2015

LDR adalah rasio antara seluruh jumlah kredit yang diberikan terhadap dana pihak ketiga. LDR digunakan untuk mengukur kemampuan bank tersebut dalam membayar kembali hutang-hutangnya serta memenuhi permintaan kredit yang diajukan ((Dewi, dkk, 2015). Lebih jelasnya pengertian LDR menurut Bank Indonesia (2013) adalah rasio kredit yang diberikan kepada pihak ketiga dalam rupiah dan valuta asing, tidak termasuk kredit kepada bank lain, terhadap dana pihak ketiga yang mencakup giro, tabungan, dan deposito dalam rupiah dan valuta asing, tidak termasuk dana antar bank Rumus perhitungan LDR adalah sebagai berikut:

$$
\text { LDR }=\frac{\text { Total kredit }}{\text { Total dana pihak ketiga }} \times 100 \%
$$

Peraturan LDR di Indonesia tertuang dalam PBI No. 15/15/PBI/2013 yang menetapkan parameter yang digunakan dalam perhitungan LDR adalah batas bawah LDR target sebesar $78 \%$ dan batas atas LDR target sebesar $92 \%$. Peraturan tersebut telah beberapa kali diubah dengan peraturan Indonesia Nomor: 17/11/PBI/2015 yang mengubah LDR menjadi LFR 2015 dengan batas bawah LFR 78\% dan batas atas 94\% yang berlaku sejak 1 Agustus 2015 kemudian peraturan tersebut empat kali diubah terakhir berdasarkan Peraturan Bank Indonesia nomor: 19/6/PBI/2017.

Kebijakan makroprudensial yang akomodatif juga ditempuh melalui ketentuan loan to funding ratio (LFR), yang kemudian disebut rasio intermediasi makroprudensial (RIM). RIM merupakan penyempurnaan dari kebijakan Giro Wajib Minimum (GWM) LFR yang dirumuskan pada tahun 2015 sebagai upaya mitigasi ketergantungan perbankan pada retail funding. Instrumen ini dikembangkan dengan memperluas pembiayaan ekonomi dari kredit ke arah pembelian surat-surat berharga berkualitas yang diterbitkan oleh korporasi nonkeuangan. (Bank Indonesia, 2019). RIM merupakan upaya peningkatan dan perluasan intermediasi dengan prinsip kehati-hatian sehingga tidak mengganggu stabilitas sistem keuangan.

LFR Bank sesuai degan Surat Edaran Bank Indonesia nomor: 17/17/DKMP tanggal 26 juni 2015 dihitung sebagai berikut:

Non-Performing Loan (NPL)

$$
\mathrm{LFR}=\frac{\text { Kredit }}{(\mathrm{DPK}+\text { Surat Berharga yang diterbitkan })} \times 100 \%
$$

NPL adalah jumlah kredit yang tidak dibayar dan tidak dapat ditagih, dengan kata lain merupakan kredit bermasalah dengan kualitas kurang lancar, diragukan dan macet (Purwoko \& Sudiyatno, 2013). NPL merupakan cerminan dari risiko kredit yaitu risiko akibat kegagalan debitur dan atau pihak lain dalam memenuhi kewajiban kepada bank. (Bank Indonesia, 2013).

Rumus perhitungan NPL adalah sebagai berikut:

$$
\mathrm{NPL}=\frac{\text { Total Kredit Kol. } 3+4+5}{\text { Total kredit }} \times 100 \%
$$

Rasio NPL pada kolom diatas diperleh dari daftar rincian kredit yang diberikan dalam laporan bulanan bank umum posisi 2 (dua) masa laporan sebelumnya sebagaimana dimaksud dalam ketentuan yang mengatur laporan bulanan bank umum (Bank Indonesia, 2015a) 
Bank dinilai memiliki potensi kesulitas yang membahayakan kelangsungan usahanya jika rasio kredit bermasalah (NPL) secara neto lebih dari 5\% dari total kredit. (Bank Indonesia, 2013).

\section{Bank Indonesia 7-day (Reverse) Repo Rate}

Bank Indonesia (2017) menyatakan bahwa BI Rate merupakan suku bunga acuan yang ditetapkan oleh Bank Indonesia sebagai salah satu sikap kebijakan moneter. BI Rate ini diumumkan ke publik yang selanjutnya menjadi acuan bagi industri perbankan Indonesia dalam menentukan tingkat suku bunga. Penetapan BI Rate ini tentu sangat dipengaruhi oleh faktor-faktor lain dalam perekonomian, seperti inflasi.

BI Rate adalah suku bunga kebijakan yang mencerminkan sikap atau kebijakan moneter yang ditetapkan oleh bank Indonesia dan diumumkan kepada publik yang dimumkan oleh Dewan Gubernur Bank Indonesia setiap rapat Dewan Gubernur bulanan dan diimplementasikan pada operasi moneter yang dilakukan Bank Indonesia melalui pengelolaan likuiditas di pasar uang untuk mencapai sasaran operasional kebijakan moneter (Bank Indonesia, 2015). BI Rate dihitung dengan menggunakan rata-rata tertimbang dan memperhitungkan bobot volume transaksi pada periode yang bersangkutan (Bank Indonesia, 2006).

Sejak 19 agustus 2018 Bank Indonesia melakukan langkah penguatan kerangka operasional kebijakan moneter melalui implementasi suku bunga kebijakan Bank Indonesia 7-day reverse repo rate (BI7DRR) guna meningkatkan efektivitas transmisi kebijakan moneter menggantikan BI Rate. BI 7-Day Repo Rate merupakan acuan baru yang memiliki hubungan yang lebih kuat dengan pasar uang, bersifat transaksional atau diperdagangkan di pasar, dan mendorong pendalaman pasar keuangan khususnya instrument repo. (Bank Indonesia, 2017b).

Penguatan kerangka operasi moneter ini merupakan hal yang lazim dilakukan oleh bank sentral dan merupakan best practice internasional dalam pelaksanaan operasi moneter. Bank Indonesia (2017) menjelaskan bahwa kerangka operasi moneter senantiasa disempurnakan untuk memperkuat efektivitas kebijakan dalam mencapai sasaran inflasi yang telah ditetapkan dan diharapkan kebijakan tersebut berpengaruh terhadap penguatan sinyal kebijakan moneter dengan suku bunga (reverse) Repo Rate 7 hari sebagai acuan utama di pasar keuangan, meningkatnya efektivitas transmisi kebijakan moneter melalui pergerakan suku bunga pasar uang dan suku bunga perbankan serta pembentukan struktur suku bunga di pasar uang antarbank (PUAB) untuk tenor 3-12 bulan.

Inflasi

Bank Indonesia (2017) menjelaskan bahwa inflasi adalah indikator yang menunjukkan fluktuasi harga barang dan jasa di masyarakat. Inflasi mengukur perubahan harga barang dan jasa dari waktu ke waktu. Angka inflasi yang positif mengindikasikan kenaikan harga barang dan jasa. Kenaikan harga dapat berimbas pada berkurangnya kemampuan masyarakat memperoleh barang dan jasa tersebut. Tingkat inflasi yang menurun dan tetap positif menunjukkan kenaikan harga yang lebih rendah dibandingkan sebelumnya. Menurut teori kuantitas, pertumbuhan beredarnya uang di masyarakat merupakan salah satu penyebab inflasi. Jumlah uang beredar yang meningkat mendorong meningkatnya harga barang dan jasa. Dengan demikian, teori ini berpendapat bahwa bank sentral berperan penting dalam menjaga stabilitas inflasi. Bank sentral memiliki kendali tertinggi atas tingkat inflasi dengan mempertahankan kestabilan jumlah uang beredar. Jika bank sentral meningkatkan jumlah uang beredar dengan cepat, tingkat harga juga akan meningkat dengan cepat yang berujung pada meningkatnya inflasi.

Inflasi merupakan salah satu bagian penting dalam menentukan kinerja perbankan. Pengaruh inflasi pada kinerja perbankan sangat ditentukan pada ketepatan memprediksi infalsi. Apabila dampak inflasi dapat diprediksi dan telah diantisipasi dengan penyesuaian suku bunga maka dapat berpengaruh positif terhadap profitabilitas, sebaliknya kegagalan dalam memprediksi inflasi dapat menyebabkan kesulitas arus cash bagi debitur yang berdampak pada kesulitan debitur dalam membayar kewajiban (Abdullah et al, 2014). 
Secara umum inflasi dihitung berdasarkan indeks harga konsumen (IHK), dengan perhitungan sebagai berikut:

$$
\mathrm{INF}=\left(\frac{\mathrm{IHK} \text { tahun } 1-\mathrm{IHK} \text { tahun } 0}{\mathrm{IHK} \text { tahun } 0}\right) \times 100 \%
$$

Hubungan Antar Konsep

CAR mencerminkan kemampuan permodalan perusahaan. Semakin tinggi CAR maka semakin baik kemampuan bank tersebut untuk menanggung risiko dari setiap aktiva produktif yang berisiko. (Wibowo \& Syaichu, 2013). Dilihat dari sisi profitabilitas, Nusantara (2009) menyatakan bahwa semakin besar CAR maka akan semakin besar pula kesempatan bank dalam menghasilkan laba, karena dari modal yang besar dapat membuat manajemen dengan leluasa menempatkan dananya kedalam aktivitas investasi yang menguntungkan. Menurut Kumalasari dan Syaichu (2016) modal dengan laba bank adalah dua hal yang berhubungan erat yang berarti apabila bank memiliki modal yang besar yang, maka semakin besar kemungkinan bank untuk menyalurkan dana yang dimiliki untuk meningkatkan pendapatan dan laba perusahaan. Namun dari hasil uji statistik dilakukan oleh peneliti tersebut CAR berpengaruh negatif terhadap ROA perbankan hal ini dapat disebabkan oleh modal yang dimiliki bank tidak dialokasikan secara efektif dan efisien pada aktiva sesuai dengan tingkat resikonya sehingga pertumbuhan CAR tidak sejalan dengan pertumbuhan ROA.

LDR merupakan ukuran likuidtas yang mengukur besarnya dana yagn ditempatkan dalam bentuk kredit yang berasal dari dana yang dikumpulkan masyarkat (Nusantara, 2009) Semakin tinggi LDR mengindikasikan semakin tinggi dana pihak ketiga yang dialurkan dalam bentuk kredit sehingga akan berpengaruh terhadap pendapatan bank senada dengan itu Dewi et al (2015) menyatakan apabila kemampuan bank dalam menyalurkan kredit terhadap dana pihak ketiga yang terkumpul adalah tinggi, maka semakin tinggi pula kredit yang diberikan pihak bank dan meningkatkan laba bank yang bersangkutan, dengan kata lain meningkatnya LDR akan membuat kinerja keuangan perbankan membaik dengan asumsi fasktor-faktor lainnya dapat diminimalisir tingkat risikonya.

Paleni et al (2017) menyatakan bahwa apabila tingkat Non-Performing Loan (NPL) rendah mengindikasikan bahwa dana yang telah disalurkan dalam bentuk kredit dapat dapat dikelola dengan baik maka perputaran dana akan semakin cepat sehingga pendapatan meningkat membuat tingkat profitabilitas yang diproksikan dengan ROA juga meningkat begitu pula sebaliknya. NPL merupakan rasio keuangan yang menunjukkan risiko kredit yang dihadapi bank akibat pemberian kredit (Sukarno \& Syaichu, 2006). Apabila suatu bank dengan tingkat NPL tinggi, maka akan memperbesar biaya, seperti biaya pencadangan aktiva produktif, sehingga berpotensi menimbulkan kerugian pada bank sehingga berdampak pada turunnya kinerja perbankan yang diukur dengan profitabilitas. Sehingga diharapkan pihak manajemen dapat mengantisipasi peningkatan NPL dengan berbagai antisipasi pengetatan alur seleksi pemberian kredit (Purwoko \& Sudiyatno, 2013).

Penelitian Jumono et al (2018) menunjukkan bahwa tingkat Inflasi berpengaruh negatif dan tidak signifikan terhadap profitabilitas bank baik dipangsa pasar tabungan dan deposito maupun kredit. Hal ini mengindikasi bahwa pihak manajemen perbankan telah mengambil langkah antisipatif melalui strategi harga dan efisiensi. Selain itu dilihat dari aspek pengaruh penetapan suku bunga Bank Indonesia (SBI) menunjukkan apabila suku bunga mengalami kenaikan maka suku simpanan dan kredit juga akan turut naik membuat masyarakat cenderung memilih untuk menyimpan uang mereka di Bank daripada untuk meminjam dana di Bank dan apabila kredit turun maka profitabilitas bank juga akan turun. Penelitian yang dilakukan oleh Wulandari, dkk (2017) juga mengemukakan bahwa tingkat inflasi dan SBI juga tidak berpengaruh terhadap kesulitan perbankan karena pihak perbankan diprediksikan mampu untuk beradaptasi dan memiliki pengendalian yang baik terhadap perubahan Inflasi dan suku bunga. 
Kebijakan penetapan suku bunga diatur oleh Bank Indonesia sebagai pemegang otoritas moneter, perbankan dan sistem pembayaran. Dalam suatu periode, apabila terjadi kenaikan suku bunga Bank Indonesia sebagai suatu tindakan untuk menjaga stabilitas moneter, akan berpengaruh terhadap ketatnya likuiditas perbankan sehingga pihak bank akan kesulitan untuk mendapatkan dana murah seperti tabungan, giro dan deposito sedangkan dilihat dari segi biaya bank (cost of fund) cenderung naik membuat bank membuat kebijakan untuk menaikan suku bunga dasar kredit dan memperbesar kemungkinan kredit bermasalah (Wibowo \& Syaichu, 2013), sehingga berpengaruh terhadap turunnya profitabilitas bank.

Inflasi didefinisikan sebagai kecenderungan kenaikan harga secara umum (Hendrayanti \& Muharam, 2013). Inflasi berpengaruh terhadap profitabilitas perbankan yang mengindikasikan bahwa dengan naiknya tingkat inflasi akan berdampak pada beban operasional perbankan meningkat serta berdampak pada meningkatnya suku bunga bank membuat keinginan masyarakat untuk meminjam dana di bank berkurang. Secara luas naiknya harga barang juga mempengaruhi kemampuan masyarakat dalam membeli serta untuk simpanan di bank juga berkurang yagn berpengaruh terhadap turunnya tingkat profitabilitas perbankan. (Dwijayanthy \& Naomi, 2009).

\section{Kerangka Pikir}

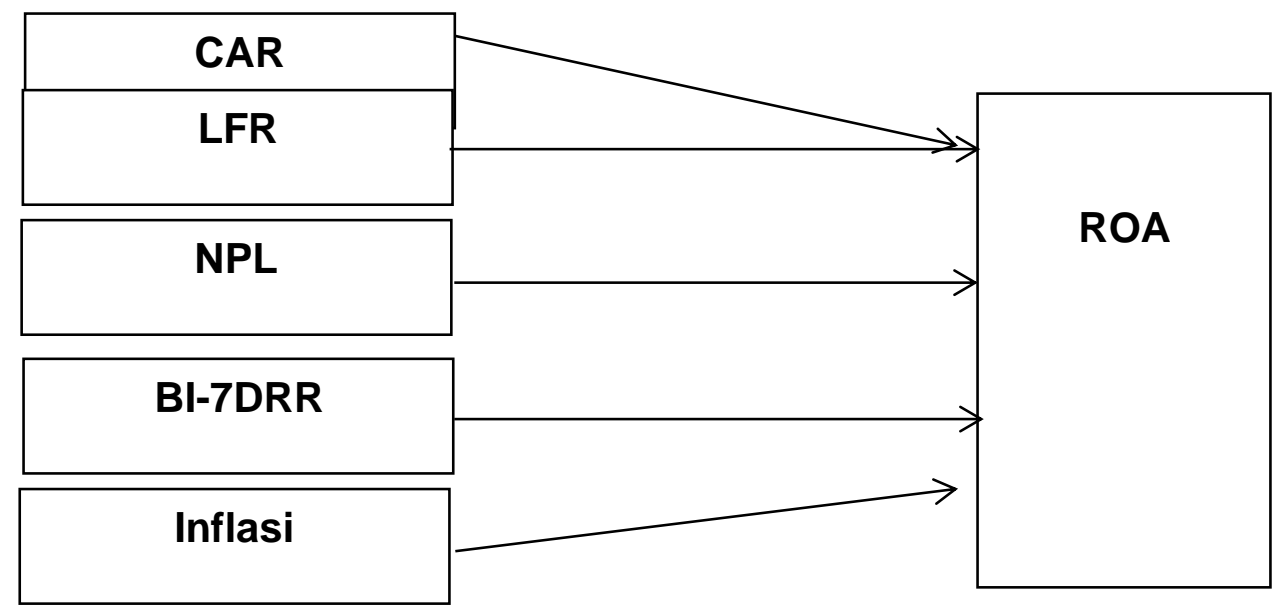

Gambar 3.1 Kerangka Proses Berpikir

Dasar penyusunan kerangka konseptual pada Figur 3.1 diatas diawali pemikiran bahwa peranan perbankan saat ini sangat dominan dalam sistem keuangan, sehingga pemahaman dan pengeloaan bank yang baik tentunya akan mendorong sistem keuangan yang baik. Pemahaman ini diperkaya dengan berbagai pemaparan mengenai pengelolaan kinerja perbankan da tingkat kesehatan yang memadai. (Purwoko \& Sudiyatno, 2013). Dalam hal ini kinerja perbankan yang diukur melalui profitabilitas yang diproksikan dengan ROA, besar kecilnya dapat dipengaruhi oleh berbagai fungsi baik fungsi internal maupun fungsi internal.

Fungsi atau faktor internal merupakan faktor yang dapat dikendalikan oleh manajemen. Dalam penelitian ini fungsi internal yang digunakan diambil dari rasio keuangan yang paling banyak digunakan oleh perbankan yaitu dilihat dari sisi risiko kecukupan modal, likuiditas dan kredit bermasalah yang terangkum dalam CAR, LDR dan NPL. Sedangkan fungsi eksternal merupakan fungsi diluar kendali manajemen ataupun faktor makroekonomi. Dalam penelitian ini diambil nilai BI 7-Day (reverse) Repo Rate, dan inflasi. Kelima variabel independen ini yang dituangkan dalam hipotesis 1 sampai dengan 5 dan dianggap memiliki pengaruh baik secara positif maupun negatif terhadap perkembangan kinerja laba perbankan yang di Indonesia yang diproksikan dengan ROA. 
Penyusunan kerangka konseptual ini dibuat untuk melihat bagaimana pengaruh kelima variabel independen tersebut secara bersama bersama terhadap ROA apakah signifikan atau tidak. Signifikansi tersebut menunjukkan seberapa besar pengaruh faktor-faktor tersebut terhadap naik turunnya ROA perbankan dalam periode penelitian yang menunjukkan seberapa efektif dan efisien perusahaan perbankan dalam menjalankan fungsinya dengan mempertimbangan risiko kecukupan modal, risiko likuiditas, risiko kredit bermasalah, risiko nilai tukar, suku bunga dan inflasi. Terakhir, ketika varabel-variabel tersebut memberikan kontribusi secara bersama-sama. Kita akan meilihat bagaiman pengaruh dari masing-masing variabel independen terhadap naik turunnya ROA perbankan dalam periode penelitian. Hal ini nantinya dapat digunakan sebagai bahan analisa baik dari pembuat kebijakan (Pemerintah dan Bank Indonesia) untuk mengambil langkah dan tindakan untuk mengantisipasi berbagai risiko yang akan muncul yang dapat mengganggu kinerja perbankan secara keseluruhan dan berdampak pada sistem perekonomian nasional serta dapat menjadi perhatian bagi masing-masing perusahaan perbankan untuk memperbaiki berbagai kekurangan dari kinerja operasional untuk mendapatkan hasil yang lebih baik. Fenomena-fenomena yang terjadi selama periode penelitian juga dapat membuat pihak-pihak yang berkepentingan mengetahui bahwa dalam kondisi pasar yang penuh kompetisi dan berbeda-beda, tidak selamanya suatu faktor dapat berpengaruh positif atau negatif atau bahkan tidak berpengaruh sama sekali terhadap profitabilitas tergantung bagaiman strategi perusahaan untuk dapat bertahan.

Hipotesa

Adapun hipotesis dalam penelitian ini adalah sebagai berikut:

Ho1: CAR, LFR, NPL,BI7DRR, dan Inflasi secara simultan tidak berpengaruh signifikan terhadap ROA perusahaan perbankan.

$\mathrm{H}_{\mathrm{a}}$ : CAR, LFR, NPL,BI7DRR, dan Inflasi secara simultan berpengaruh signifikan terhadap ROA perusahaan perbankan.

Ho2: CAR secara parsial tidak berpengaruh signifikan terhadap ROA perusahaan perbankan

$\mathrm{H}_{\mathrm{a}}$ : CAR secara parsial berpengaruh signifikan terhadap ROA perusahaan perbankan

H03: LFR secara parsial tidak berpengaruh signifikan terhadap ROA perusahaan perbankan

Ha3: LFR secara parsial berpengaruh signifikan terhadap ROA perusahaan perbankan

Ho4: NPL secara parsial tidak berpengaruh signifikan terhadap ROA perusahaan perbankan

$\mathrm{H}_{\mathrm{a}} 4$ : NPL secara parsial berpengaruh signifikan terhadap ROA perusahaan perbankan

H05: BI7DRR secara parsial tidak berpengaruh signifikan terhadap ROA perusahaan perbankan

Ha5: BI7DRR secara parsial berpengaruh signifikan terhadap ROA perusahaan perbankan

Ho6: Inflasi secara parsial tidak berpengaruh signifikan terhadap ROA perusahaan perbankan

Ha6: Inflasi secara parsial berpengaruh signifikan terhadap ROA perusahaan perbankan

\section{METODE PENELITIAN}

Jenis Penelitian

Penelitian ini merupakan penelitian kuantitatif dengan menggunakan metode kausalitas. Penelitian Kausalitas adalah penelitian yang menyatakan hubungan satu variabel menyebabkan perubahan variabel lainnya. Dimana variabel yang dipengaruhi adalah variabel dependen dan variabel yang mempengaruhi adalah variabel independen. (Hartono, 2012). Dalam penelitian ini bertujuan untuk melihat pengaruh dari variabel internal yang terdiri dari CAR, LDR dan NPL serta variabel eksternal yang terdiri dari BI Rate, Nilai tukar dan Infasi terhadap profitabilitas perbankan yang diproksikan dengan ROA.

Lokasi atau Objek Penelitian

Lokasi penelitian adalah negara kesatuan republik Indonesia dengan pertimbangan: 
1. Merupakan negara penulis, sehingga peneliti merasa tertarik untuk melihat bagaimana kondisi perekonomian di Indonesia.

2. Kemudahan penulis dalam memperoleh data-data yang akan digunakan dalam penelitian dan lebih mudah dipahami.

Objek penelitian ini adalah perusahaan perbankan di Indonesia yang secara konsisten mempublikasikan laporan keuangan dan memiliki jumlah aset terbesar selama periode 2016-2018.

Populasi dan Sampel

Dalam melakukan penelitian, populasi yang akan dijadikan objek penelitian harus ditentukan dengan cermat dan benar. Populasi merupakan sekumpulan entitas yang lengkap yang dapat terdiri atas orang, kejadian atau benda, yang memiliki sejumlah karakteristik yang umum (Wibisono, 2013). Populasi dalam penelitian ini adalah perusahaan perbankan yang terdaftar di Bursa Efek Indonesia dan karena tidak semua perusahaan mempublikasikan laporan keuangannya secara lengkap, maka penulis melakukan pemilihan sampel dengan menggunakan teknik sampel pertimbangan (purposive) dengan kriteria sebagai berikut:

1. Perusahaan perbankan yang secara konsisten tercatat di Bursa Efek Indonesia pada tahun 2016-2018

2. Perusahaan perbankan yang mempublikasikan laporan keuangannya secara lengkap mulai tahun 20162018

3. Perusahaan yang secara konsisten termasuk dalam 11 besar perusahaan perbankan dengan jumlah aset terbesar.

Daftar perusahaan yang sesuai dengan kriteria tersebut dicari dan dipilih oleh penulis lewat situs resmi BEI dan situs resmi BI.

Tabel 4.3.1. Jumlah Sampel Penelitian

\begin{tabular}{llll}
\hline Kriteria & 2016 & 2017 & 2018 \\
\hline $\begin{array}{l}\text { 1.Perusahaan perbankan yang secara } \\
\text { konsisten tercatat di BEI dan mempublikasikan } \\
\text { laporan keuangan (Populasi) }\end{array}$ & 29 & 29 & 29 \\
$\begin{array}{l}\text { 2. Perusahaan perbankan yang konsisten } \\
\text { konsisten dengan jumlah aset terbesar (Sampel) }\end{array}$ & 11 & 11 & 11 \\
\hline
\end{tabular}


Tabel 4.3.2. Daftar Bank dengan Jumlah Aset Terbesar tahun 2016 -2018

\begin{tabular}{|c|l|c|r|}
\hline NO & \multicolumn{1}{|c|}{ NAMA BANK } & KODE BANK & $\begin{array}{c}\text { TOTAL ASET } \\
\text { (Triliun Rp) }\end{array}$ \\
\hline 1 & Bank Rakyat Indonesia (Persero) Tbk. & BBRI & $1,269.90$ \\
\hline 2 & Bank Mandiri (Persero) Tbk. & BMRI & $1,202.25$ \\
\hline 3 & Bank Central Asia Tbk. & BBCA & 824.79 \\
\hline 4 & Bank Negara Indonesia (Persero) Tbk. & BBNI & 808.57 \\
\hline 5 & Bank Tabungan Negara (Persero) Tbk. & BBTN & 306.44 \\
\hline 6 & Bank CIMB NiagaTbk. & BNGA & 266.78 \\
\hline 7 & Bank Pan Indonesia Tbk & PNBN & 207.20 \\
\hline 8 & Bank Danamon Indonesia Tbk. & BDMN & 186.76 \\
\hline 9 & Bank Maybank Indonesia Tbk. & BNII & 177.53 \\
\hline 10 & Bank OCBC NISP Tbk. & NISP & 173.58 \\
\hline 11 & Bank Permata Tbk. & PNBN & 152.89 \\
\hline
\end{tabular}

Sumber: Laporan Tahunan 11 Perbankan tahun 2016-2018

Metode Pengumpulan Data

Penelitian ini merupakan jenis penelitian kuantitatif sehingga data-data yang dikumpulkan adalah data sekunder yang berasal dari sumber-sumber tercetak, dimana data tersebut telah dikumpulkan oleh pihak lain sebelumnya. Penulis menggunakan fasilitas internet untuk mengunduh secara langsung seluruh informasi dari situs resmi BEI, BI, BPS, dan Laporan Tahunan Perusahaan Perbankan yang diunduh langsung dari website resmi masing-masing Bank. Seluruh data yang ada kemudian dimasukkan kedalam software spreadsheet Microsoft Excel kemudian diolah menggunakan software statistik SPSS, dan hasil yang diperoleh kemudian dianalisa lebih lanjut. Selain mengunduh data lewat internet, penulis juga melakukan pencarian literatur dari buku-buku, serta media lainnya untuk mendapatkan informasi pendukung yang diperlukan dalam penelitian ini.

\section{Sumber Data}

Sumber data yang digunakan dalam penelitian ini adalah buku, laporan perusahaan, jurnal, dan refrensi artikel internet lainnya

\section{Teknik Analisis Data}

Penelitian ini dilakukan untuk mengetahui pengaruh faktor internal yang terdiri dari CAR, LDR, dan NPL serta faktor eksternal yang terdiri dari BI 7-day Repo Rate, dan Inflasi terhadap profitabilitas perbankan, baik pengaruh secara simultan maupun secara parsial. Untuk mengetahui pengaruh variabel bebas terhadap variabel terikat digunakan model regresi linear berganda. Namun, sebelum penulis melakukan analisis regresi, penulis perlu melakukan uji asumsi dasar untuk menguji normalitas data dan uj asumsi klasik untuk memastikan bahwa tidak ada multikolinearitas, heterokedastisitas, dan autokorelasi dalam model regresi linear yang digunakan. 
Uji Normalitas

Menurut Wibisono (2013), uji normalitas merupakan suatu jenis statistik untuk menentukan apakah suatu data terdistribusi normal atau tidak.Pengujian ini dilakukan dengan menggunakan uji statistik One Sample Kolmogorov-Smirnov, dimana data dinyatakan terdistribusi normal apabila nilai signifikansinya lebih besar dari angka 0,05.

Model Regresi

Setelah uji asumsi klasik dilakukan, selanjutnya penulis melaksanakan pengujian hipotesis menggunakan regresi linear berganda untuk menguji pengaruh variabel independen secara simultan dan parsial terhadap variabel dependen. Dalam penelitian ini variabel dependen yang digunakan adalah ROA sedangkan variabel independen yang digunakan terbagi atas faktor internal yang terdiri dari CAR, LDR dan NPL serta faktor eksternal yang terdiri dari BI 7-Day Repo Rate dan tingkat Inflasi.

Model hubungan antara variabel dependen dengan variabel-variabel independen diatas disusun dalam fungsi atau persamaan sebagai berikut:

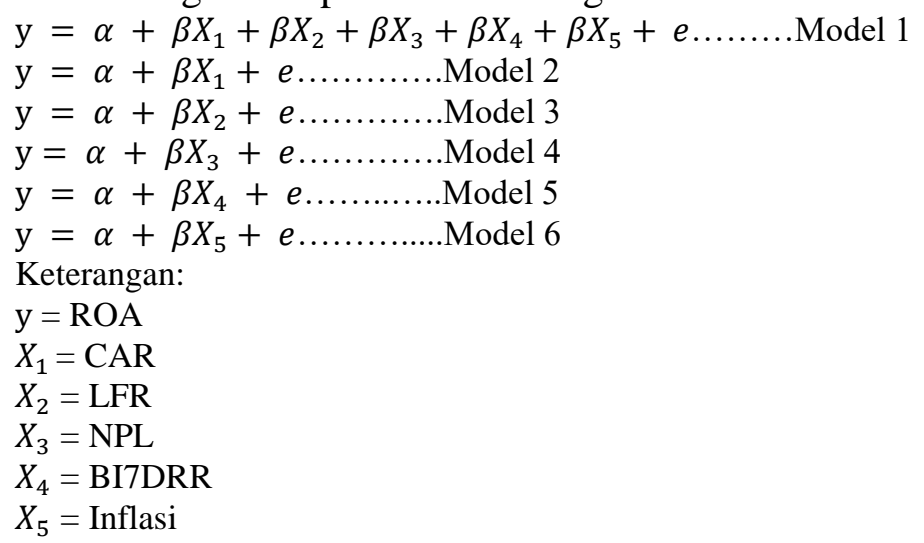

Analisa Data dan Pengujian Hipotesis

Data yang sudah dimasukkan dalam spreadsheet diolah melalui aplikasi statistik SPSS untuk diuji dengan menggunakan model statistik yang telah ditentukan. Hasil pengolahan kemudian di analisa, apabila nilai significance probability (p-value) lebih kecil dari 0.05 maka hipotesa $N u l l\left(\mathrm{H}_{0}\right)$ yang telah ditetapkan dinyatakan di tolak dan $\mathrm{H}_{\mathrm{a}}$ dinyatakan diterima. Jika nilai $\mathrm{p}$-value ternyata lebih besar dari 0.05 , maka $\mathrm{H}_{0}$

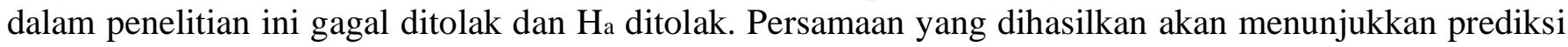
seberapa besar perubahan nilai variabel dependen ROA ketika nilai variabel independen CAR, LDR, NPL, BI 7-Day Repo Rate, dan tingkat Inflasi berubah, sehingga bisa dilihat pengaruh dari variabel independen tersebut terhadap variabel dependen. Penelitian ini juga menghitung kekuatan masing-masing variabel bebas dalam menentukan variabel terikat dan untuk menginterpretasikan variabel mana yang memberikan pengaruh paling besar terhadap rentabilitas perbankan dalam suatu model regresi linear maka digunakan standardized beta cofficients.

Koefisien determinasi juga dianalisa untuk mengetahui besarnya persentase variasi variabel independen yang digunakan mampu menjelaskan variasi variabel dependen dan sumbangan pengaruh variabel independen secara bersama-sama terhadap variabel dependen. Pada model regresi linear sederhana digunakan analisa $\mathrm{R}_{2}$ untuk penentuan penerimaan beberapa hipotesa parsial dan pada model regresi linear berganda digunakan adjusted $\mathrm{R}_{2}$ sebagai nilai $\mathrm{R}_{2}$ yang telah disesuaikan. Apabila nilainya sama dengan 0 maka tidak ada sedikitpun persentase sumbangan pengaruh yang diberikan variabel independen terhadap variabel dependen, sehingga bisa dikatakan bahwa variasi variabel independen dalam penelitian ini tidak 
dapat menjelaskan sedikitpun variasi variabel dependen. Sebaliknya apabila nilainya sama dengan 1 maka variabel independen berpengaruh sempurna terhadap variabel.

Definisi Operasional Variabel dan Indikator

Definisi operasional dan indikator dari masing-masing variabel dalam penelitian ini adalah sebagai berikut:

ROA - (Y)

Merupakan rasio yang digunakan untuk mengukur kemampuan manajemen dalam memperoleh keuntungan atau laba secara keseluruhan dilihat dasi sisi penggunaan aset. (Hendrayanti \& Muharam, 2013).

CAR $\left(\mathrm{X}_{1}\right)$

Rasio kecukupan modal uang menunjukkan kemampuan bank dalam mempertahankan modal yang mencukupi dan kemampuan manajemen bank dalam mengidentifikasi, mengukur, mengawasi, dan mengontrol risiko-risiko yang timbul yang dapat berpengaruh terhadap besarnya modal bank (Sukarno \& Syaichu, 2006).

$\operatorname{LDR}\left(\mathrm{X}_{2}\right)$

Merupakan rasio kedit dibagi dengan dana pihak ketiga. Dimana kredit yang dimaksudkan adalah total kredit yang diberikan kepada pihak ketiga (tidak termasuk antar Bank) sedangkan dana pihak ketiga mancakup giro, tabungan, dan deposito (tidak termasuk antar Bank. (Bank Indonesia, 2011).

NPL $\left(\mathrm{X}_{3}\right)$

Risiko kredit yang dihadapi bank akibat pemberian kredit dan investasi dana bank pada portfolio bank yang berbeda (Sukarno \& Syaichu, 2006). Menurut Dewi, dkk (2015) Rasio NPL digunakan untuk mengukur kemampuan manajemen bank dalam mengelola kredit bermasalah.

BI 7-Day Repo Rate $\left(\mathrm{X}_{4}\right)$

Suku bunga kebijakan yang mencerminkan sikap atau kebijakan moneter yang ditetapkan oleh bank Indonesia dan diumumkan kepada publik (Bank Indonesia, 2015).

Inflasi (X5)

Kecenderungan naiknya harga barang dan jasa pada umumnya yang berlangsung secara terus menerus. (Badan Pusat Statistik, 2017).

Tabel 4.5. Variabel - Variabel dan Pengukurannya.

\begin{tabular}{|c|c|c|}
\hline Notasi & Deskripsi & Pengukuran \\
\hline ROA (y) & Return On Asset & Laba sebelum pajak \\
\hline $\operatorname{CAR}\left(X_{1}\right)$ & Capital Adequacy & $\begin{array}{c}\overline{\text { Rata - rata total aset }} \times 100 \% \\
\text { Modal bank }\end{array}$ \\
\hline & Ratio & $\overline{\text { Aktiva tertimbang menurut resiko }}$ X 100\% \\
\hline $\operatorname{LFR}\left(X_{2}\right)$ & Loan to Funding Ratio & \\
\hline \multirow{3}{*}{$\operatorname{NPL}\left(X_{3}\right)$} & Non Performing Loan & Kredit \\
\hline & & $\begin{array}{c}\overline{\text { (DPK }+ \text { Surat Berharga yang diterbitkan }} \times 100 \% \\
\text { Total Kredit Kol. } 3+4+5\end{array}$ \\
\hline & & $\begin{array}{c}\text { Total kredit } \\
\text { X 100\% }\end{array}$ \\
\hline $\mathrm{INF}\left(X_{4}\right)$ & Tingkat Inflasi & $\left(\frac{\mathrm{IHK} \text { tahun } 1-\mathrm{IHK} \text { tahun } 0}{\mathrm{IHK} \text { tahun } 0}\right) \times 100 \%$ \\
\hline $\operatorname{BI7DRR}\left(X_{5}\right)$ & BI 7-Day Repo Rate & Nilainya diumumkan oleh Dewan Gubernur BI setiap \\
\hline$\alpha$ & Koefisien Konstanta & Rapat Dewan Gubernur bulanan \\
\hline$\beta$ & Regression slope & \\
\hline$e$ & Error term & \\
\hline
\end{tabular}




\section{HASIL PENELITIAN}

Hasil Uji Regresi

Hasil Uji Secara Simultan (Uji Model)

Tabel 5.1.3.1 dibawah ini merepresentasikan hasil uji pengaruh secara simultan variable independen yang terdiri dari CAR, LFR, NPL, BI7DRR dan Inflasi terhadap profitabilitas Perbankan di Indonesia periode tahun 2016-2018.

\section{Tabel 5.1.3.1 Pengaruh CAR, LDR, NPL, BI 7DRR dan Inflasi Secara Simultan}

\begin{tabular}{|ll|r|r|}
\hline \multirow{2}{*}{ Model } & \multicolumn{2}{|c|}{ Unstandardized Coefficients } \\
\cline { 3 - 4 } & (Constant) & B & \multicolumn{2}{|c|}{ Std. Error } \\
\hline 1 & $\mathrm{X}_{1}$ & 2,513 & 4,631 \\
$\mathrm{X}_{2}$ &, 259 &, 052 \\
& $\mathrm{X}_{3}$ &,- 013 &, 015 \\
& $\mathrm{X}_{4}$ &,- 857 &, 083 \\
& $\mathrm{X}_{5}$ &,- 182 &, 324 \\
& &,- 288 &, 709 \\
\hline
\end{tabular}

$Y=2,513+0,259 X_{1}-0,013 X_{2}-0,857 X_{3}-0,182 X_{4}-0,288 X_{5}$

Tabel 5.1.3.1.1 Tabel Anova

\begin{tabular}{|rl|r|r|r|r|r|}
\hline \multicolumn{1}{|l|}{ Model } & \multicolumn{1}{|c|}{$\begin{array}{c}\text { Sum of } \\
\text { Squares }\end{array}$} & df & Mean Square & F & \multicolumn{1}{c|}{ Sig. } \\
\hline 1 & Regression & 71,607 & 5 & 14,321 & 47,345 &, $000 \mathrm{a}$ \\
& Residual & 8,167 & 27 &, 302 & & \\
& Total & 79,774 & 32 & & & \\
\hline
\end{tabular}

a. Predictors: (Constant), $\mathrm{X}_{1}, \mathrm{X}_{2}, \mathrm{X}_{3}, \mathrm{X}_{4}, \mathrm{X}_{5}$

b. Dependent Variable: $y$

Hasil penelitian menunjukkan bahwa CAR, LFR, NPL, BI7DRR, dan Inflasi secara simultan diduga berpengaruh signifikan terhadap ROA perbankan sehingga $\mathrm{H}_{0} 1$ ditolak dan $\mathrm{H}_{\mathrm{a}} \mathrm{l}$ diterima terlihat dari $p$ value secara keseluruhan sebesar 0,000 lebih kecil dari batas signifikansi dengan $\alpha=0,05$. Adanya pengaruh signifikan dari hasil uji statistik variabel bebas terhadap variabel terikat pada uji regresi menunjukkan model ini dapat digunakan untuk uji pengaruh secara parsial. 


\section{Hasil Uji Hipotesis}

Secara parsial pengaruh dari lima variabel independen CAR, LDR, NPL, BI7DRR dan Inflasi terhadap profitabilitas perusahaan perbankan yang diproksikan dengan ROA adalah sebagai berikut:

\section{Tabel 5.3.2. Pengaruh CAR, LDR, NPL, BI7DRR dan Inflasi secara parsial}

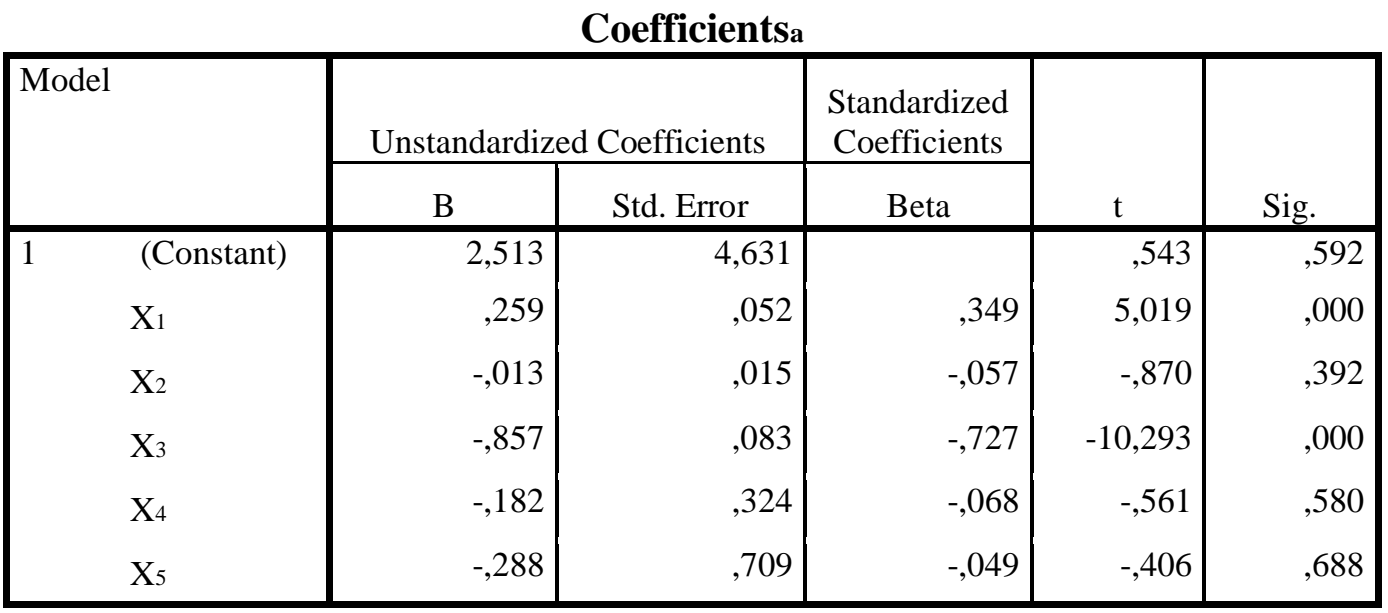

a. Dependent Variable: y

\section{Pengaruh CAR tehadap ROA}

Tabel 5.3.2. menunjukkan bahwa CAR secara parsial diduga berpengaruh positif dan signifikan terhadap perubahan ROA sehingga $\mathrm{H}_{0} 2$ ditolak dan $\mathrm{H}_{\mathrm{a}} 2$ diterima terlihat dari $p$-value sebesar 0,000 lebih kecil dari nilai batas signifikansi $\alpha=0,05$ dengan standardized coefficients beta 0,349 dimana setiap penambahan 1 poin CAR mempengaruhi ROA sebesar 0,260.

Pengaruh LFR terhadap ROA

Tabel 5.3.2. merepresentasikan bahwa secara parsial LFR diduga tidak berpengaruh signifikan terhadap ROA ditunjukkan dengan $p$-value sebesar 0,392 lebih besar dari nilai batas signifikansi $\alpha=0,05$. Berdasarkan hasil tersebut maka dapat disimpulkan bahwa $\mathrm{H}_{0} 3$ diterima dan $\mathrm{H}_{\mathrm{a}} 3$ ditolak.

Pengaruh NPL terhadap ROA

Hasil uji statistik pada Tabel 5.3.2. menunjukkan bahwa NPL diduga berpengaruh negatif dan signifikan terhadap ROA sehingga $\mathrm{H}_{0} 4$ ditolak dan $\mathrm{H}_{3} 3$ diterima terlihat dari p-value sebesar 0,000 lebih kecil dari nilai batas signifikansi $\alpha=0,05$ dengan standardized coefficients beta,- 727 dimana setiap penambahan 1 poin NPL akan mempengaruhi turunnya ROA sebesar 0,727 .

Pengaruh BI7DRR terhadap ROA

Hasil perhitungan statistik pada Tabel 5.3.2. menunjukkan bahwa BI7DRR tidak berpengaruh signifikan terhadap ROA perbankan di Indonesia tahun 2016-2018 terlihat dari $p$-value $=0,580$ lebih besar dari batas nilai signifikansi $\alpha=0,05$. Sehingga dapat disimpulkan bahwa $\mathrm{H}_{0} 5$ diterima dan $\mathrm{H}_{\mathrm{a}} 5$ ditolak.

Pengaruh Inflasi terhadap ROA

Hasil penelitian pada Tabel 6.3.2. menunjukkan bahwa Inflasi tidak berpengaruh signifikan terhadap ROA dengan $p$-value $=0,688$ melebihi batas nilai signifikansi $\alpha=0,05$. Berdasarkan hasil tersebut maka dapat disimpulkan bahwa $\mathrm{H} 06$ diterima dan $\mathrm{H}_{\mathrm{a}} 6$ ditolak. 
Pembahasan Hasil Penelitian

Pengaruh CAR, LDR, NPL, BI7DRR dan Inflasi Secara Simultan Terhadap ROA

Berdasarkan hasil penelitian yang dipresentasikan pada Tabel 10 bahwa faktor-faktor independen yang digunakan dalam penelitian ini yaitu CAR, LDR, NPL, BI7DRR, dan inflasi berpengaruh signifikan terhadap tingkat ROA dari 11 perusahaan perbankan yang memiliki jumlah aset terbesar di Indonesia dan secara konsisten mempublikasikan laporan keuangannya di Bursa Efek Indonesia (BEI) pada tahun 20162018. Hasil ini sesuai dengan teori yang dikemukakan bahwa profitabilitas perbankan yang diprosikan dengan ROA dipengaruhi oleh faktor internal dan eksternal, di satu sisi dapat memberikan dampak positif terhadap ROA perbankan namun di sisi lain juga dapat memberikan dampak yang negatif. Hasil penelitian diatas menunjukkan bahwa CAR atau kecukupan modal minimum perbankan yang kuat sangat berguna bagi pengembangan usaha dan penyaluran kredit dapat berpengaruh positif bagi peningkatan profitabilitas sehingga Bank Indonesia (2013) melalui peraturan no. 15/12/PBI/2013 menetapkan kebijakan mengenai penyediaan modal minimum (CAR) sesuai dengan profil resiko dimana keberadaan CAR sangat diperlukan untuk memitigasi berbagai kompleksitas usaha.

Dewi et al (2015) menyatakan bahwa LDR merupakan indikator untuk efektifitas dana yang dikumpulkan. Hasil penelitian menunjukkan pengelolaan LDR yang tidak efektif dapat berpengaruh negatif terhadap profitabilitas mengindikasikan kredit yang diberikan tidak sebanding dengan total dana pihak ketiga yang berhasil dihimpun baik dari Penempatan tabungan, giro, deposito serta penempatan instrumen keuangan, tingkat NPL dan BI7DRR yang tinggi membuat bank lebih selektif dalam memberikan kredit sehingga dapat mengurangi tingkat kredit bermasalah namun disisi lain berpengaruh terhadap jumlah pendapatan yang diperoleh bank. Dilihat dari sisi makroekonomi menunjukan bahwa laju inflasi yang terkendali selama periode analisa dapat berpengaruh terhadap peningkatan ROA Perbankan. Apabila hal ini dapat terus diimplementasikan dengan baik berdasarkan prinsip kehati-hatian dan penerapan manajemen risiko yang sistematis didukung dengan peran serta pemberi kebijakan dalam hal ini Bank Indonesia dalam mengatur stabilitas moneter dan sistem keuangan di Indonesia maka profitabilitas perbankan di Indonesia yang diproksikan dengan ROA akan terus meningkat.

Pengaruh CAR Secara Parsial Terhadap ROA

Hasil penelitian menunjukkan bahwa CAR berpengaruh positif dan signifikan terhadap ROA perbankan yang termasuk dalam 11 besar aset di Indonesia yang mengindikasikan bahwa bank-bank tersebut berlomba-lomba untuk mempertahankan struktur permodalan lebih dari CAR yang telah ditetapkan oleh regulator serta memanfaatkan modalnya dengan optimal karena semakin efisien modal bank yang digunakan untuk aktivitas operasional maka semakin tinggi potensi untuk memperoleh laba baik dalam bentuk perluasan kantor cabang, peningkatan infrastruktur dan teknologi perbankan untuk meningkatkan daya saing, program pengembangan karyawan, program promosi kepada nasabah dan dapat digunakan untuk setiap usaha dalam rangka meningkatkan pendapatan perbankan. Hasil penelitian ini senada dengan penelitian yang dilakukan oleh Sudiyatno dan Suraso (2010) dan Sukarno \& Syaichu (2006) dan dalam peneltiannya menyatakan bahwa tingkat CAR yang ideal sangat mempengaruhi kepercayaan masyarakat untuk menyimpan dananya di bank. Hal ini berbeda dengan penelitian yang dilakukan oleh Nusantara (2009) yang mendapati hasil bahwa CAR tidak berpengaruh signifikan terhadap ROA perbankan dengan alasan bahwa perbankan cenderung untuk menggunakan dengan cermat setiap permodalannya dan cenderung dipergunakan untuk pertahanan kesehatan Bank. Serta penelitian yang dilakukan oleh Kumalasari \& Syaichu (2013) mendapati hasil bahwa CAR berpengaruh secara negatif signifikan dikarenakan modal bank tidak dialokasikan sepenuhnya pada aktiva yang menghasilkan pendapatan. 
Hal yang mendasari perbedaan dengan beberapa perbedaan dengan penelitian terdahulu dapat disebabkan oleh bedanya cakupan pasar yang dimiliki perbankan yang tercatat dalam 11 besar aset nasional dan perbankan go-public lainnya, perbedaan waktu dan objek penelitian.

Pengaruh LFR Secara Parsial Terhadap ROA

Hal yang menarik dalam penelitian ini adalah ketika variabel LFR dianalisa secara simultan dengan variable independen lainnya maupun secara parsial menunjukkan bahwa LDR yang sekarang telah diubah menjadi LFR dengan menambahkan penyertaan Surat Berharga pada tahun penelitian menunjukkan dampak negatif terhadap ROA. Hal ini disebabkan oleh adanya fenomena perbankan berlomba-lomba memberikan kredit kepasar namun tanpa diimbangi dengan penyediaan dana murah sehingga sumber dana yang digunakan oleh pihak perbankan untuk menyalurkan kredit berasal dari instrument-instrumen keuangan dengan biaya dana mahal. Dilihat dari analisa secara parsial, hasil penelitian mengindikasikan bahwa pada tahun penelitian industri perbankan mengalami masalah likuiditas sehingga LFR tidak berpengaruh signifikan terhadap peningkatan ROA terdampak dari melemahnya perekonomian Global. Pasar uang sepi bahkan mayoritas masyarakat juga masih mempertimbangkan untuk menyimpan atau mengambil kredit di Bank, terjadi kerentanan karena dalam retail funding yang pertumbuhannya melambat yang berdampak pada meningkatnya funding gap yang menyebabkan tekanan likuiditas ketika perbankan mengunakan alat likuid sebagai sumber dana alternatif, sehingga ruang ekspansi penyaluran kredit menjadi terbatas, Padahal pihak regulator melalui peraturan Bank Indonesia Nomor: 17/11/PBI/2015 yang mengubah LDR menjadi LFR 2015 menetapkan batas bawah LFR 78\% dan batas atas 94\% yang berlaku sejak 1 Agustus 2015.

Kebijakan makroprudensial yang akomodatif ini ditempuh melalui ketentuan loan to funding ratio (LFR), yang kemudian disebut rasio intermediasi makroprudensial (RIM) ini sebenarnya dikembangkan oleh pihak regulator perbankan dengan tujuan memperluas pembiayaan ekonomi dari kredit ke arah pembelian surat-surat berharga berkualitas yang diterbitkan oleh korporasi nonkeuangan. Namun hasil kebijakan ini belum terlalu berdampak baik bagi industri perbankan terlihat nilai LFR beberapa bank besar masih diatas $94 \%$. Walaupun posisi LFR beberapa bank yang menjadi objek penelitian berada dalam posisi optimal dan sehat, memberikan ruang ekspansi kredit yang cukup serta masih berada dalam batas ketentuan regulator.

Hasil ini berbeda dengan teori yang telah dikemukakan bahwa LDR digunakan untuk mengukur kemampuan bank tersebut dalam membayar kembali hutang-hutangnya serta memenuhi permintaan kredit yang diajukan (Dewi, dkk, 2015) dimana dari hasil penelitian menunjukkan bahwa LDR berpengaruh positif dan signifikan terhadap ROA ketika besarnya DPK yang berhasil dihimpun sediiringi dengan besarnya jumlah kredit yang berhasil disalurkan dalam penelitian yang telah dilakukan sehingga ROA turut meningkat.

Efektifitas pengelolaan dana pihak ketiga dan disalurkan kedalam bentuk kredit yang prudent akan memberikan pengaruh yang signifikan terhadap ROA apabila didukung dengan pemberian kredit yang tepat sasaran dan pengawasan yang ketat. Serta penelitian yang dilakukan oleh Sudiyatno dan Suroso (2010). Upaya yang dapat dilakukan oleh manajemen untuk meningkatkan kinerja bank (ROA) adalah dengan meningkatkan dana pihak ketiga (DPK) melalui peningkatan kepercayaan kepada nasabah, karena dengan kepercayaan ini nasabah akan menyimpan dananya di bank.

Pengaruh NPL Secara Parsial Terhadap ROA

Bank Indonesia (2013) mendefinisikan bahwa NPL merupakan cerminan dari risiko kredit yaitu risiko akibat kegagalan debitur dan atau pihak lain dalam memenuhi kewajiban kepada bank. (Bank Indonesia, 2013). Sehingga menurut Purwoko dan Sudiyatno (2013) apabila suatu bank dengan kondisi NPL tinggi, maka akan memperbesar biaya pencadangan aktiva produktif maupun aktiva lainnya yang 
berpotensi menimbulkan kerugian pada pihak bank dan dampaknya mempengaruhi turunnya kinerja. Hasil penelitian mereka juga menujukkan bahwa NPL berpengaruh negatif signifikan terhadap ROA kondisi ini menuntut manajemen untuk melakukan analisis yang lebih baik lagi ketika pihak Manajemen memutuskan untuk meyalurkan kredit ke masyarakat (nasabah), sehingga meminimalisir terjadinya kredit bermasalah. Sesuai dengan teori yang dipaparkan, hasil penelitian ini menunjukkan bahwa secara parsial NPL berpengaruh signifikan terhadap ROA dari 11 perusahaan perbankan dengan aset terbesar di Indonesia hal ini mengindikasikan bahwa risiko kredit bermasalah masih menjadi momok terhadap turunnya keuntungan industri perbankan. Penerapan manajemen risiko yang berkesinambungan, usaha-usaha restrukturisasi kredit bermasalah, penghapusan kredit NPL dan pertumbuhan kredit yang diiringi dengan penerapan prinsip kehati-hatian dalam operasional perbankan dan penyelesaian kredit bermasalah yang tepat dan terarah sangat berpengaruhi terhadap kelangsungan bisnis perbankan di Indonesia.

Pengaruh BI7DRR Secara Parsial Terhadap ROA

Secara parsial BI7DRR tidak berpengaruh signifikan terhadap ROA perbankan yang digunakan sebagai objek penelitian. Kebijakan Bank Indonesia untuk mengubah BI Rate menjadi BI7DRR sangat berdampak pada sektor riil .Hal positif lainnya yang diambil bahwa perusahaan-perusahaan perbankan yang menjadi objek penilitian telah menyiapkan berbagai langkah antisipatif dalam menghadapi berbagai fluktuasi suku bunga baik suku bunga pinjaman maupun kredit sehingga usaha perbankan tidak terdampak oleh volatilitas suku bunga serta brand image yang telah dimiliki membuat bank-bank tersebut tetap memiliki fundamental yang kuat. Hasil penelitian ini senada dengan penelitian yang dilakukan oleh Naomi dan Dwijayanthy (2009). Penelitian yang dilakukan oleh Wulandari, dkk (2017) juga diperoleh hasil bahwa suku bunga berpengaruh negatif dan tidak signifikan terhadap ROA karena diduga perbankan telah melakukan upaya terhadap potensi kenaikan suku bunga.

Pengaruh Inflasi Secara Parsial Terhadap ROA

Seperti halnya dengan BI7DRR hasil pengolahan data menunjukkan bahwa Inflasi secara parsial tidak berpengaruh signifikan terhadap pertumbuhan ROA perbankan di Indonesia. Walaupun secara luas dapat kita lihat bahwa inflasi membuat harga-harga barang yang dipergunakan masyarakat menjadi naik serta mempengaruhi perekonomian masyarakat, namun usaha perbankan sebagai perantara keuangan harus tetap berjalan guna menunjang jalannya perekonomian suatu negara. Apabila terjadi inflasi,maka Bank Indonesia yang memiliki fungsi dan tanggung jawab untuk menjaga kestabilian moneter berusaha untuk melakukan berbagai kebijakan untuk mengendalikan Inflasi dan salah satu upaya untuk mengantisipasi inflasi adalah dengan menentukan BI7DRR, pihak perbankan juga mengimplementasikan setiap perubahan kebijakan dengan melakukan berbagai perubahan baik suku bunga tabungan dan kredit, tidak berhenti disitu perusahaan perbankan secara berkelanjutan berlomba-lomba untuk mengembangkan produk perbankan, pelayanan dan infrastuktur guna meningkatkan pendapatan operasional lainnya yang berpengaruh terhadap meningkatnya profitabilitas perbankan secara keseluruhan.

Penelitian ini sejalan dengan hasil penelitian Hendrayanti \& Muharam (2012), meskipun hasilnya tidak signifikan, bukan berarti bank dapat mengabaikan inflasi dalam meningkatkan ROA. Semakin tinggi tingkat inflasi, maka akan semakin baik kinerja bank dalam menghasilkan laba. Hal ini dikarenakan tingkat inflasi yang terantisipasi oleh manajemen bank dapat menunjukkan bahwa bank dapat menyesuaikan tingkat suku bunga dengan tepat dalam rangka meningkatkan pendapatan lebih cepat dari biaya sehingga dapat menghasilkan laba yang tinggi. 


\section{KESIMPULAN DAN SARAN}

Kesimpulan

Penelitian ini bertujuan untuk menganalisa faktor-faktor yang mempengaruhi ROA Perbankandan diprediksi dengan menggunakan variabel faktor internal yang terdiri dari CAR, LFR dan NPL serta faktor eksternal yang terdiri dari BI7DRR dan Inflasi. Terdapat 6 model persamaan yang terangkum dalam 6 hipotesis yang diuji. Untuk menguji pengaruh secara simultan digunakan uji regresi linear berganda dan uji regresi linear sederhana untuk menguji pengaruh masing-masing variabel independen secara parsial terhadap profitabilitas perbankan. yaitu:

Berdasarkan hasil penelitian yang telah dipaparkan pada BAB V maka ditarik beberapa kesimpulan

1. CAR, LFR, NPL, BI7DRR dan Inflasi secara simultan berpengaruh signifikan terhadap ROA perbankan

2. CAR secara parsial berpengaruh secara positif signifikan terhadap ROA perbankan

3. NPL secara parsial berpengaruh negatif signifikan terhadap ROA perbankan

4. LFR secara parsial tidak berpengaruh signifikan terhadap ROA perbankan

5. BI7DRR secara parsial tidak berpengaruh signifikan terhadap ROA perbankan

6. Inflasi secara parsial tidak berpengaruh signifikan terhadap ROA perbankan

Saran

Keseluruhan hasil penelitian ini diharapkan dapat memberikan kontribusi positif bagi pihak - pihak yang berkepentingan. Adapun saran yang dapat diberikan penulis untuk perkembangan industri perbankan Nasional dan perkembangan kualitas penelitian selanjutnya adalah sebagai berikut:

\section{Regulator (Bank Indonesia)}

Pihak Regulator dan Pemerintah diharapkan mampu mempertahankan koordinasi yang berkesinambungan guna meningkatkan fungsi intermediasi perbankan sehingga pergerakan sektor riil akan semakin baik, melalui berbagai macam terobosan untuk meningkatkan efisiensi perbankan, menghindari persaingan perbankan yang tidak sehat, mencapai sasaran inflasi dan keseimbangan eksternal yang pada akhirnya perusahaan perbankan dapat memberikan kontribusi terhadap stabilitas dan pertumbuhan ekonomi Nasional.

\section{Industri Perbankan Indonesia}

Pihak perbankan diharapkan dapat menetapkan langkah-langkah strategis yang tepat dan berdampak positif terhadap bisnis bank ke depan dengan memperhatikan penerapan prinsip kehati-hatian, kepatuhan terhadap peraturan dan kebijakan yang telah ditetapkan, manajemen resiko yang efektif, kedepan pihak perbankan juga harus terus berinovasi di bidang diversifikasi produk perbankan dan tidak hanya bertumpuh pada produk kredit saja namun harus berupaya untuk meningkatkan fee-based income serta sadar akan perubahan strategi perbankan sejalan dengan perkembangan di era financial technology.

\section{Penelitian Selanjutnya}

Untuk keperluan penelitian selanjutnya disarankan untuk dapat menyempurnakan berbagai keterbatasan dalam penelitian ini baik dari metode penelitian yang digunakan, objek penelitian, serta dapat membuat perubahan dan perkembangan variabel penelitian yang terkait dengan profitabilitas seperti menambahkan variabel pengukuran lainnya yang berhubungan dengan variabel-variabel yang akan diukur seperti cost efficiency yang tidak hanya mencakup kegiatan operasional melainkan seluruh aktivitas 
perbankan yang selalu dilandaskan pada kebijakan Bank Indonesia dan OJK terbaru. Selain itu dengan akan diterapkannya IFRS 9 atau PSAK-71 pada 1 Januari 2020 maka sebaiknya dilakukan penelitian tentang dan ancaman penerapan PSAK-71 terhadap industri perbankan karena besarnya pencadangan kerugian ekspektasian baik untuk 12 bulan dan sampai dengan jatuh tempo kredit akan sangat menggerus profitabilitas perbankan apabila tidak diantisipasi serta pengaruh penerapan financial technology terhadap industri perbankan juga harus menjadi salah satu fokus penelitian selanjutnya.

\section{DAFTAR PUSTAKA}

Abate, T. W., \& Mesfin, E. A. (2019). Factors affecting profitability of commercial Banks in Ethiopia. International Journal of Research and Analytical Reviews, 6(1), 881-891.

Abbas, F., Iqbal, S., \& Aziz, B. (2019). The Impact of bank capital, bank liquidity and credit risk on profitability in postcrisis period: A comparative study of US and Asia. Cogent Economics \& Finance (2019), 7: 1605683, doi: 10.1080/23322039.2019.1605683.

Abdullah, M. N., Parvez, K., Ayreen, S. (2014). Bank specific, industry specific anda macroeconomic determinants of commercial bank profitability: a case of Bangladesh. World Journal of Social Sciences, 4(3), 82-96.

Almaqtari, F. A., Al-Homaidi, E. A., Tabash, M. I., \& Farhan, N. H. (2018). The determinants of profitability of Indian commercial banks: A panel data approach. Int J Fin Econ. 2019;24:168185. doi: 10.1002/ijfe.1655.

Al-Harbi, A. (2019). The determinants of conventional banks profitability in developing and underdeveloped OIC countries. Journal of Economics, Finance and Administrative Science, 24(47), 4-28. doi:10.1108/JEFAS-05-2018-0043.

Badan Pusat Statistik (2015). Laporan bulanan data sosial ekonomi, (Publikasi Nomor: 03220.1505). Diakses dari http://www.bps.go.id/index.php/publikasi/downloadFile/1214.

Bank Indonesia (2011). Booklet Perbankan Indonesia 2011. Diakses dari: https://www.ojk.go.id/Files/201401/BookletPerbankanIndonesia2011_1390364364.pdf.

Badan Pusat Statistik. (2017). Laporan perekonomian Indonesia 2017, (Publikasi Nomor: 07330.1710). Diakses dari https://www.bps.go.id/publication/2017/09/27/96607b0fa1ba5649ce573500/laporanperekonomian-indonesia-2017.html

Bank Indonesia (2015). Explanation of BI Rate. 18 Mei 2015. Diakses dari http://www.bi.go.id/en/moneter/bi-rate/penjelasan/Contents/Default.aspx.

Bank Indonesia. (2015). Peraturan Bank Indonesia Nomor: 17/11/PBI/2015 tentang perubahan atas peraturan Bank Indonesia nomor 15/15/pbi/2013 tentang giro wajib minimum bank umum dalam rupiah dan valuta asing bagi bank umum konvensional. Diakses dari https://www.bi.go.id/id/peraturan/ssk/Pages/pbi_171115.aspx 
Bank Indonesia. (2014). Kajian Stabilitas Keuangan No. 23, September 2014. Diakses dari http://www.bi.go.id/id/publikasi/perbankan-dan-stabilitas/kajian/Pages/KSK_230914.aspx

Bank Indonesia. (2019). Kajian Stabilitas Keuangan No 32. Diakses dari: https://www.bi.go.id/id/publikasi/perbankan-dan-stabilitas/kajian/Pages/KSK_3219.aspx

Bank Indonesia. (2017). Laporan Perekonomian Indonesia 2016. Diakses dari: https://www.bi.go.id/id/publikasi/laporan-tahunan/perekonomian/Pages/LPI_2016.aspx

Bank Indonesia. (2019). Laporan Perekonomian Indonesia 2018. Diakses dari: https://www.bi.go.id/id/publikasi/laporan-tahunan/perekonomian/Pages/LPI_2018.aspx

Bank Indonesia. (2013). Peraturan Bank Indonesia nomor 15/02//PBI/2013 tentang penetapan status dan tindak lanjut pengawasan bank umum konvensional. Diakses dari http://www.bi.go.id

Bank Indonesia. (2013). Peraturan Bank Indonesia nomor 15/15//PBI/2013 tentang giro wajib minimum bank umum dalam rupiah dan valuta asing bagi bank umum konvensional. Diakses dari http://www.bi.go.id.

Bank Indonesia. (2013). Peraturan Bank Indonesia nomor 15/12//PBI/2013 tentang kewajiban penyediaan modal minimum bank umum. Diakses dari http://www.bi.go.id.

Bank Indonesia. (2006). Statistik ekonomi keuangan di Indonesia.VIII(11).

Bojare, K., \& Romanova, I. (2017). The factors affecting the profitability of Banks: the case of Latvia. European Research Studies Journal, XX(3A), 905-919.

Corporatefinanceinstitute.com. (2019, 02 Desember). Return on asset and roa formula. Diakses dari: https://corporatefinanceinstitute.com/resources/knowledge/finance/return-on-assets-roa-formula/

Dewi, L. E., Herawati, N. 7., \& Sulindawati, L. G. E., (2015). Analisis pengaruh NIM, BOPO, LDR, dan NPL terhadap profitabilitas. E-Journal S1 Ak. Universitas Pendidikan Ganesha, 3(1).

Dwijayanthy, F., \& Naomi, P. (2009). Analisis pengaruh inflasi, BI rate, dan nilai tukar mata uang terhadap profitabilitas bank periode 2003-2007. Karisma, 3(2), 87-98.

Flamini, V., Mc.Donald, C., \& Sumacher, L. (2009). The determinants of commercial bank profitability in Sub-Saharan African. IMF working paper, 2009.

Ghosh, S. K., \& Maji, S. G. (2019). Profitability of banks in India: impacts of market structure and risk. Journal of Applied Finance \& Banking, 9(6), 181-202.

Ghozali, I. (2005). Aplikasi Analisis Multivariate dengan Program SPSS. Semarang: Badan Penerbit Universitas Diponegoro

Gujarati, D. N. (2003). Basic Econometrics. New York: McGraw-Hill/Irwin 
Hartono, J. (2012). Metodologi Penelitian Bisnis Salah Kapra dan Pengalaman-Pengalaman. Yogyakarta: BPFE.

Hastuti, S. P., \& Ghozali, I. (2019). Analisis faktor-faktor yang mempengaruhi profitabilitas perbankan gopublic di Indonesia. Diponegoro Journal of Accounting, 8(3), 1-10.

Hendrayanti, S., \& Muharam, H. (2013). Analisis pengaruh faktor internal dan eksternal terhadap pofitabilitas perbankan. Diponegoro Journal of Management, 2(2), 1-15.

Jumono, S., Sugiyanto, S., \& Mala, C. M. F. (2018) Why have bank profitability been high in Indonesia? An analysis using dynamic panel data approach. Journal of Economic and Management Perspectives, $12(2), 353-367$.

Kawshala, H. \& Panditharathna, K. (2017). The factors effecting on Bank profitability. International Journal of Scientific and Research Publications, 7(2), 212-216.

Kumalasari, Y. \& Syaichu, M. (2016). Analisis faktor-faktor yang mempengaruhi profitabilitas pada bank umum syariah di Indonesia periode 2010 - 2014. Diponegoro Journal of Management, 5(3), 1-11.

Margaretha, F., \& Letty (2017). Faktor-faktor yang mempengaruhi kinerja keuangan perbankan di Indonesia. Manajemen Keuangan, 6(2), 84-96.

Nure, G (2019). The impact of specific banking, industrial and macroeconomic factors on bank profitability: Evidence from the Albanian banking system. Business and Economic Research, 9(2), 182-198. doi: 10.5296/ber.v9i2.14724.

Nusantara, A. B. (2009). Analisis pengaruh NPL, CAR, LDR dan BOPO terhadap profitabilitas bank. (Master tesis, Universitas Diponegoro). Diakses dari http://eprints.undip.ac.id.

Otoritas Jasa Keuangan (2018). Statistik Perbankan Indonesia Vol. 17 No. 1, Desember 2018.

Otoritas Jasa Keuangan (2018). Booklet Perbankan Indonesia 2018 Edisi 5. Diakses dari:

Paleni, H., Hidayat, S. \& Jatmiko, D. P. (2017). Determinants of profitability: evidence from Indonesian firms. International Journals of Economic Perspectives, 11 (3), 1049 - 1057.

Prasidha, D. K. (2015). Dampak nilai tukar dan risk-based bank rating terhadap prediksi kondisi perbankan Indonesia. (Jurnal ilmiah, Universitas Brawijaya).

Purwoko, D., \& Sudiyatno, B. (2013). Faktor-faktor yang mempengaruhi kinerja bank (Studi empirik pada industry perbankan di Bursa Efek Indonesia). Jurnal Bisnis dan Ekonomi, 20(1), 25-39.

Rawlin, R., Shanmugam, R., \& Bhat, V. (2014). A comparison of key determinants on profitability of India's largest public dan private sector banks. European Journal of Business and Management, 6(34), 62-68., K

Subramanyam, K. R., \& Wild, J. J (2009). Financial Statemen Analysis. Singapura: McGraw-Hill. 
Sudiyatno, B., \& Suroso, J. (2010). Analisis pengaruh dana pihak ketiga, BOPO, CAR dan LDR terhadap kinerja keuangan pada sektor perbankan yang go public di Bursa Efek Indonesia, 2005-2008. Dinamika Keuangan dan Perbankan, 2(2), 125-137

Sukarno, K. W., \& Syaichu, M. (2006). Analisis faktor-faktor yang mempengaruhi kinerja bank umum di Indonesia. Jurnal Studi Manajemen \& Organisasi, 3(2), 46-58.

Tulung, J. E., Saerang, I. S., \& Pandia, S. (2018). The influence of corporate governance on the intellectual capital disclosure: a study on Indonesian private banks. Banks and Bank Systems, 13(4), 61-72.

Tulung, J. E., and Ramdani, D. (2016). The Influence of Top Management Team Characteristics on BPD Performance. International Research Journal of Business Studies, Volume 8 Nomor 3, Pp.155-166.

Tulung, J. E., and Ramdani, D. (2018). Independence, Size and Performance of the Board: An Emerging Market Research. Corporate Ownership \& Control, Volume 15, Issue 2, Winter 2018.

Ugoani, J. N. N. (2019). Performance management and bank profitability in Nigeria. Business, Management and Economics Research, 5(3), 49-56. doi: 10.32861/bmer.53.49.56.

Watuseke, C., Worang, F. G., \& Tielung, M. V. J. (2019). Determinants of bank profitability in Indonesia. Jurnal EMBA, 7(1), 211-220.

Wibisono, D. (2013). Panduan Penyusunan Skripsi, Tesis \& Disertasi. Yogyakarta: ANDI.

Wibowo, E. S. \& Syaichu, M. (2013). Analisis pengaruh suku bunga, inflasi, car, bopo, npf terhadap profitabilitas bank syariah. Diponegoro Journal of Management, 2(2), 1-10.

Wulandari, Y., Musdolifah., \& Kusairi, S. (2017). The impact of macroeconomics and internal factors on banking distress. International Journal of Economic and Financial Issues, 7(3), 429 -436. 